\title{
PERSEPSI MASYARAKAT TERHADAP KOMUNITAS ANAK PUNK DI KOTA PEKALONGAN
}

\author{
Fitri Awan Arif Firmansyah' ${ }^{1)}$, Amelia Putri Nirmala ${ }^{2)}$ \\ ${ }^{1.2}$ Fakultas Psikologi, Universitas Selamat Sri \\ Email: ${ }^{1}$ fitriawanarif@yahoo.co.id, ${ }^{2}$ amelnirmala9@gmail.com
}

\begin{abstract}
This study aims to determine the perception of society towards the behavior of punk children in Pekalongan City. This research including field research that is qualitative. Sources of data in this study were taken from the data primary or basic data taken and obtained from field research through observation, interviews, documentation and population of five people in Pekalongan City, while secondary data is complementary data which obtained from documentation related to the problems in this research. Results This study shows that the public's perception of the behavior of punk children is considered trash society because they have negative attitudes and behaviors. What factors led to the existence of punk children? are family economic pressures, prohibitions from parents, want freedom, lazy personality.
\end{abstract}

Keywords: Public perception, punk children, Pekalongan

\section{PENDAHULUAN}

Remaja merupakan periode kehidupan yang penuh dengan dinamika dan perubahan, di mana masa tersebut terjadi perkembangan dan perubahan yang sangat pesat. Masa remaja meninggalkan tahap kehidupan masa kanakkanak untuk menuju tahap berikutnya, yaitu tahap kedewasaan. Masa remaja dikatakan sebagai masa krisis dikarenakan belum adanya pegangan selain itu kepribadiannya dalam proses mengalami penbentukan, dengan kata lain masa remaja dikatakan sebagai masa pencarian jati diri dalam kehidupannya. Masa remaja dikatakan sebagai masa dengan penuh tekanan, konflik setra ketidaktahuan yang mana ketidaktahuan mereka membentuk menjadi pribadi yang idealis. Di kota besar di Indonesia sekarang ini banyak sekali kelompok remaja yang bertingkah laku menyimpang dari normanorma masyarakat sekitar. Kelompok tersebut biasanya disebut dengan kelompok anak punk. Punk merupakan kelompok atau komunitas busana atau fashion yang digunakan serta tingkah laku mereka, seperti potongan rambut yang diwarnai warna terang, memakai sepatu boots, celana jeans, pakaian lusuh, membawa gitar, serta berjaket kulit. Generasi remaja yang mengidentikan dirinya sebagai seorang anak punk. Sebagian remaja mengartikan kehidupan anak punk yang bebas dan tanpa aturan sehingga pengetahuan yang kurang dan setengah-setengah tersebut membuat mereka mempunyai perspektif negatif di kalangan masyarakat, salah satu contohnya yaitu mereka melakukan atau menongkrong di tempat umum dan minum minuman keras. Masyarakat awam sendiri menilai kehidupan anak punk negatif dengan tidak mengikuti aturan-aturan norma yang berlaku. Gaya punk sendiri merupakan gaya remaja budaya Barat yang telah sampai di Indonesia dan remaja Indonesia beberapa telah mengenal dan menerapkannya dalam kehidupan mereka, dan telah menyebabkan budaya nenek moyang terlebur oleh budaya-budaya yang negatif. Gaya anak punk mempunyai sisi negatif di dalam pandangan masyarakat dikarenakan tampilannya yang cenderung menyeramkan dan berperilaku negatif seperti minum minuman keras, mengamen dan juga cenderung dianggap tidak pernah menjalankan ibadah. Selain itu seringnya berkumpul di malam hari menimbulkan dugaan bahwa mereka mungkin juga suka terjerat seks bebas dan penggunaan narkoba. Jumlah anak punk di Indonesia memang tidak banyak tapi ketika mereka terjun atau berkumpul di jalanan mereka cukup 
menarik perhatian masyarakat sekitar dengan gayanya seperti rambutnya yang mohawk dan warnanya yang mencolok. Selain itu dipadukan dengan aksesoris seperti rantai, gelang, celana jeans, jaket kulit dan baju yang lusuh membuat image negatif anak punk dan anti sosial (Widya, 2010:14). Beberapa masyarakat berpendapat kegiatan negatif anak sudah tidak dapat ditoleransi lagi oleh masyarakat, karena masyarakat merasa terganggu apabila ada komunitas punk yang berada di sekitar tempat tinggal masyarakat, masyarakat seolah dibatasi ruang geraknya oleh anggota punk, walaupun sebenarnya anggota punk tidak pernah membatasi ruang gerak masyarakat. Masyarkat mempunyai pemikiran seperti ini karena mereka takut untuk lewat di depan komunitas yang dandanannya tidak aturan ini. Dan dari tampilan fisik, masyarakat juga sudah bisa menebak bahwa tindakan-tindakan yang akan mereka perbuat adalah tindakan yang onar, yang sudah tentu sangat tidak disukai masyarakat. Berbagai kesan dan stigma negatif masyarakat Surabaya ditujukan terhadap komunitas anak muda ini. Mulai mereka dianggap kriminal, preman, brandal, perusuh, pemabuk, pengobat, urakan, dan hingga orangorang yang dianggap berbahaya. Hampir di setiap kota, keberadaan komunitas anak punk dipandang sebagai masalah yang meresahkan.

Banyak persepsi tentang sejarah punk mulai dari ketidakbisanya terikat dengan aturan dan menginginkan kebebasan tanpa diikat norma. Namun punk sendiri sebenarnya berasal dari sejarah pekerja London atau Amerika Serikat yang menyatakan kekecewaannya pada politik pejabat dan kemerosotan moral petinggi negara, di mana mereka mengkritiknya lewat lirik lagu dan simbol-simbol yang dikenakan punk. Dari hasil pencarian data awal banyak sekali persepsi tentang keberadaan komunitas anak punk di Kota Pekalongan, mulai dari pandangan negatif bahwasanya anak punk selalu berkaitan dengan tindakan negatif, dan beberapa mengatakan bahwa anak punk tidak semuanya berperilaku negatif. Adapun pengertian persepsi merupakan pesan atau pandangan dari individu mengenai suatu peristiwa atau objek pengamatan (Jalaludin, 2007). Alex Sobur (2003) membagi proses seleksi menjadi tiga tahapan yaitu seleksi, interpretasi, dan reaksi. Dari pembahasan permasalahan di atas peneliti ingin mengetahui: 1) Bagaimana pandangan atau persepsi masyarakat pada komunitas anak punk yang berada di Kota Pekalongan?; dan 2) Apa saja faktor yang memepengaruhi persepsi masyarakat pada komunitas anak punk di Kota Pekalongan?

\section{KAJIAN PUSTAKA}

\subsection{Persepsi}

Menurut kamus lengkap psikologi, persepsi adalah 1) proses mengetahui atau mengenali objek dan kejadian objektif dengan kejadian indera; 2) kesadaran dari proses-proses organis, 3) satu kelompok penginderaan dengan penambahan arti-arti yang berasal dari pengalaman di masa lalu; dan 4) kesadaran intutif mengenai kebenaran langsung atau keyakinan yang serta merta mengenai sesuatu (Chaplin, 2005). Persepsi adalah proses pemahaman atau pemberian makna atas suatu informasi terhadap stimulus. Stimulus didapat dari proses penginderaan terhadap objek, peristiwa atau hubungan-hubungan antar gejala yang selanjutnya diproses oleh otak (Sumanto, 2014). Sugihartono (2007) mengemukakan bahwa persepsi merupakan kemampuan atau proses panca indera dalam menerjemahkan stimulus yang masuk ke dalam alat indera manusia. Persepsi manusia terdapat perbedaan sudut pandang dalam penginderaan yang mempersepsikan sesuatu itu baik atau persepsi yang positif maupun persepsi negatif yang akan mempengaruhi tindakan manusia yang tampak atau nyata. Menurut Mulyana (2000) persepsi adalah inti komunikasi, sedangkan penafsiran (interpretasi) adalah inti persepsi, yang identik dengan penyandian-balik (decoding) dalam proses komunikasi. Selanjutnya Mulyana (2000) mengemukakan persepsilah yang menentukan pemilihan suatu pesan dan mengabaikan pesan lain. Menurut Rakhmat (2005) mengungkapkan bahwa persepsi adalah pengalaman tentang objek, peristiwa, atau hubungan-hubungan yang diperoleh dengan menyimpulkan informasi dan menafsirkan pesan. Persepsi ialah memberikan makna pada stimuli inderawi (sensory stimuli). 
Sedangkan menurut Kimbal Young (Walgito, 1981) mengatakan, "persepsi adalah sesuatu yang menunjukkan aktivitas merasakan, menginterpretasikan dan memahami objek, baik fisik maupun sosial". Jalaludin (2011) secara etimologis mengemukakan persepsi atau dalam bahasa Inggris perception berasal dari bahasa latin perceptio, dari percipere, yang artinya menerima atau mengambil, persepsi adalah pengalaman tentang objek, peristiwa atau hubungan-hubungan yang diperoleh dengan menyimpulkan informasi dan menafsirkan pesan. Persepsi ialah memberikan makna pada stimulus inderawi (Jalaludin,2011).

\subsection{Anak Punk}

Menurut Jhon (1997) secara bahasa punk adalah sumbu, seorang (pemuda) yang tidak berpengalaman, berarti buruk, rendah, gregetan, orang ceroboh, sembrono, ugalugalan. Pemuda yang ikut gerakan masyarakat, dengan menyatakan lewat musik, gaya berpakaian, dan gaya rambut khas. Punk tidak dapat diartikan sesederhana itu, karena istilah punk sudah selama ini di Indonesia, masyarakat lebih banyak melihat punk sebagai gaya hidup daripada musiknya.

Arti punk sebenarnya bukanlah musik atau fashion yang kita ketahui pada hari ini. Tetapi punk sebenarnya adalah atittude/sikap yang lahir dari sifat memberontak, tidak puas hati, marah dan benci, dari sifat-sifat inilah lahirnya punk. Rasa tidak puas hati dan marah pada sesuatu terutama tindakan yang menindas ditunjukkan dan dimasukkan ke dalam musik dan pakaian mereka. Fenomena punk yang ditangkap oleh masyarakat adalah sekelompok orang (punkers) yang berkumpul pada lokasi tertentu dengan berpakaian lusuh dan atributatribut aau aksesoris yang dipakai seperti bretel, ikat pinggang spike, sepatu boots, jeans strectch, kaos oblong, jaket kulit yang dipenuhi emblem, rambut dengan gaya mohawk. (Siti Sugiyati 2014).

\section{METODE PENELITIAN}

Sesuai dengan penelitian yang penulis teliti, maka jenis penelitian ini adalah penelitian kualitatif deskriptif. Moelong (2013) mengemukakan penelitian kualitatif merupakan penelitian bertujuan untuk memahami fenomena yang dialami oleh seseorang seperti fenomena tentang perlaku, persepsi, motivasi dengan cara mendeskripsikan dalam bentuk kata-kata dan bahasa pada konteks khusus yang alamiah. Dalam hal ini penelitian bertujuan untuk mengetahui dan mendeskripsikan persepsi masyarakat terhdap keberadaan anak punk di Kota Pekalongan. Teknik pengumpulan data yang digunakan adalah observasi, wawancara, dan dokumentasi. Populasi dalam penelitian ini yaitu masyarakat Kota Pekalongan. Teknik pengambilan sampel di sini menggunakan purposive random sampling, Menurut Arikunto (2006), purposive random sampling merupakan teknik pengambilan sampel yang tidak berdasarkan aturan (random), daerah, ataupun strata. Pengambilan sampel ini berdasarkan adanya pertimbangan pada tujuan tertentu. Subjek penelitian ini adalah orang yang memberikan informasi terkait anak punk. Kriteria subjek dalam penelitian ini yaitu individu berusia 25-50 tahun dan masyarakat asli Kota Pekalongan yang sering beraktivitas di daerah Kota Pekalongan berlatar belakang dari masyarakat biasa, tokoh agama serta pemerintahan. Penelitian ini menggunakan 10 responden, responden terdiri dari berbagai usia dan profesi, usia responden rata-rata adalah 25-50 tahun terdiri dari 7 lakilaki dan 3 perempuan.

\section{HASIL DAN PEMBAHASAN}

Dari hasil wawancara yang dilakukan peneliti, peneliti menemukan bahwasanya keberadaan anak punk di Kota Pekalongan yaitu negatif. Hal tersebut didapatkan dari hasil wawancara kepada masyarakat dan tokoh agama di Kota Pekalongan. Berdasarkan hasil jawaban wawancara yang peneliti peroleh, seperti beberapa hal berikut.

Persepsi masyarakat tentang anak punk dianggap menyimpang dalam kehidupan seharihari karena memiliki tingkah laku yang jelek. Anak punk dianggap anak yang bebas dan tidak mau mengikuti norma sehingga melakukan apapun yang mereka mau. Anak punk tidak menghiraukan lingkungan sekitar. Anak punk pun dianggap orang yang tidak taat dengan agamanya. Perilaku anak punk di Kota Pekalongan dianggap sebagai perilaku yang menyimpang dari norma-norma dan aturan di masyarakat. Hal ini dipertegas oleh Setiadi 
(2011) yang menyatakan tindakan meyimpang yaitu tindakan yang tidak sesuai dengan norma dan aturan di masyarakat, di mana mereka melampui batas atau aturan masyarakat yang sudah baku.

Banyak interpretasi masyarakat tentang anak punk, juga ada beberapa yang tidak menghiraukanya karena dianggap bukan perbuatan kriminal. Bagi mereka pandangan negatif itu merupakan sebuah kesalahpahaman karena punk yang mereka lihat di pinggirpinggir jalan bukan merupakan makna dari punk yang sebenarnya bahkan tidak mengerti makna punk yang sebenarnya. Hal ini diunggah oleh informan bernama Syaqiq yang mengaggap bahwa interpretasi anak masyarakat terhadap anak punk cenderung negatif daripada positif. Karena dari sepuluh informan hanya dua informan yang beranggapan positif dan yang lainya negatif.

Tabel 1 Hasil Wawancara kepada Masyarakat

\begin{tabular}{|c|c|c|}
\hline No & Subjek & Dialog/Pendapat \\
\hline 1 & $\mathrm{AH}$ & $\begin{array}{l}\text { "Anak punk itu kalau dari pandangan } \\
\text { saya mereka kaya malas-malasan } \\
\text { mas, gak mau kerja maune enak- } \\
\text { enakan aja ngamen minta-minta } \\
\text { padahal usia masih muda gak tau } \\
\text { gunanya apa mereka di jalanan kaya } \\
\text { gitu ganggu mata" }\end{array}$ \\
\hline 2 & AP & $\begin{array}{l}\text { "Mereka itu kalau saya lihat ngapain } \\
\text { sih di jalan, tak lihat gak mandi } \\
\text { kotor, cewek-cewek pun ikut merokok } \\
\text { kadang lihat di tv ada yang kriminal } \\
\text { juga, mabuk-mabukan, berhentiin } \\
\text { kendaraan" }\end{array}$ \\
\hline 3 & FA & $\begin{array}{l}\text { "Anak jalanan dan punk itu harus } \\
\text { dikasih pembinaan disekolahkan, } \\
\text { karena dari pandangan saya mereka } \\
\text { akan rugi sendiri nantinya dengan } \\
\text { kegiatan yang kotor gak jelas dan } \\
\text { lebih merugikan banyak orang gitu, } \\
\text { kadang mereka suka mabuk-mabukan } \\
\text { juga" }\end{array}$ \\
\hline 4 & NS & $\begin{array}{l}\text { "Saya melihat anak punk itu kaya } \\
\text { kurang suka mas dengan penampilan } \\
\text { mereka, gitaran dan kurang terawat } \\
\text { pakainya." }\end{array}$ \\
\hline 5 & WH & $\begin{array}{l}\text { "Mereka walau gak jahat tapi kalo } \\
\text { kehidupan dan penampilan mereka } \\
\text { seperti itu ya tetep kelihatan bukan } \\
\text { anak baik-baik mas, apalagi sampai } \\
\text { mabuk-mabukan, merokok di usia } \\
\text { yang masih belia" }\end{array}$ \\
\hline 6 & $\mathrm{TH}$ & $\begin{array}{l}\text { "Anak punk itu yang di jalan mereka } \\
\text { haruse gak ada, karena dari } \\
\text { pandangan saya ganggu kehidupan }\end{array}$ \\
\hline
\end{tabular}

\begin{tabular}{|c|c|c|}
\hline No & Subjek & Dialog/Pendapat \\
\hline & & $\begin{array}{l}\text { kota mas, cara yang baik itu banyak } \\
\text { untuk menghabiskan masa muda }\end{array}$ \\
\hline 7 & VN & $\begin{array}{l}\text { "Saya masih belum bisa melihat anak } \\
\text { punk sisi positifnya karena ya gitu } \\
\text { yang tak lihat mas, walaupun katanya } \\
\text { ada sisi positifnya" }\end{array}$ \\
\hline 8 & KL & $\begin{array}{l}\text { "Anak punk itu rata-rata melanggar } \\
\text { norma mas, seperti tidur di jalan dl } \\
\text { gitu, dulu kasus pembunuhan di } \\
\text { Pekalongan kan juga dilakukan anak } \\
\text { punk kalo gak salah mas" }\end{array}$ \\
\hline 9 & ST & $\begin{array}{l}\text { "Anak punk kalo padangan saya } \\
\text { selama ini selama mereka gak neko- } \\
\text { neko ya gak apa-apa mas" }\end{array}$ \\
\hline 10 & YY & $\begin{array}{l}\text { "Kalo anak punk gak jahat sih mas } \\
\text { paling cuma di jalanan saja, } \\
\text { aktivitasnya yang saya lihat. saya } \\
\text { juga lihat mereka pernah bantu } \\
\text { orang" }\end{array}$ \\
\hline
\end{tabular}

Banyak persepsi negatif tentang anak punk di Kota Pekalongan. Hal ini terjadi karena gaya dan kehidupan mereka tidak sesuai dengan norma masyarakat dan kehidupan warga negara Indonesia sehingga dipandang sebelah mata dan negatif oleh sebagian masyarakat. Jadi dapat disimpulkan bahwa keberadaan anak punk masih dianggap negatif oleh kalangan masyarakat karena kegiatan mereka seperti berkumpul di persimpangan jalan, menggunakan baju lusuh serta mabuk-mabukan di pinggir jalan.

Selain itu dari hasil wawancara yang dilakukan peneliti kepada lima anak punk di Kota Pekalongan, faktor-faktor yang mempengaruhi anak punk atau mereka yang tergabung dalam komunitas punk yaitu mereka yang ingin kebebasan tidak terikat dengan aturan atau norma serta ingin mendapatkan uang dengan cara yang mudah tanpa harus bekerja dengan keras seperti kehidupan temantemannya. Tradisi turun temurun yang berubah dalam berbagai bentuk sesuai tingkat ekonomi mereka yang mendambakan segala sesuatu dengan mudah tanpa harus bersusah payah. Berkumpulnya seseorang ke dalam sebuah komunitas karena adanya faktor-faktor pengikat. Menurut Jalaludin (2005) kekuatan pengikat komunitas yaitu kepentingan bersama belandaskan asal usul bersama seperti latar belakang budaya, masa lalu dan kesamaan nasib. 


\section{KESIMPULAN}

Berdasarkan hasil penelitian diketahui bahwa interpretasi masyarakat terhadap keberadaan anak punk di Kota Pekalongan cenderung negatif dikarenakan gaya berpakaian mereka yang tidak pada umumnya serta kehidupan mereka yang menyimpang dari norma serta aturan yang berlaku contohnya seperti menongkrong di persimpangan jalan, mengamen, mabuk-mabukan, memberhentikan truk yang berjalan. Hal ini mengakibatkan pandangan masyarakat terhadap anak punk sebagai anak yang berandal dan tidak mempunyai masa depan yang jelas dan dapat disimpulkan bahwa pandangan masyarakat terhadap anak punk lebih ke negatif daripada ke positif.

Persepsi masyarakat Kota Pekalongan terhadap anak punk yaitu sebagai sampah atau penganggu pandangan mata dikarenakan perilakunya yang lebih ke arah negatif, anak punk dianggap anak yang bebas dan tidak mengikuti aturan yang layak di dalam masyarakat. Anak punk dianggap sebagai makhluk yang kurang dalam religiusitas dan akhlaknya. Faktor-faktor yang mempengaruhi seseorang individu memutuskan menjadi anak punk yaitu seperti keputusasaan, ekonomi, adanya pola asuh orang tua yang terlalu ketat, kemalasan pada diri individu yang membuatnya ingin mendapatkan sesuatu dengan cara yang instan. Dalam hal ini pemerintah harus memberi pembinaan kepada anak punk melalui edukasi dan pendidikan dan bagi orang tua juga harus mengetahui bagaimana cara-cara mendidik anak agar mereka tetap berkembang dengan baik.

\section{REFERENSI}

Alex Sobur. (2003).__Psikologi Umum. Bandung: Pustaka Setia.

Chaplin, J P. (2005). Kamus Lengkap Psikologi. Jakarta : Rajawali Pres

Rakhmat Jalaludin.2007. Psikologi Komunikasi.Jakarta: Remaja Rosda Karya.

Rakhmat, Jalaludin, 2005. Psikologi Komunikasi, edisi revisi. Bandung: Remaja Rosdakarya.
Setiadi. Elly M dan Usman Kolip. Pengantar Sosiologi, Pemahaman Fakta Dan Gejala Permasalahan Sosial: Teori, Aplikasi, dan Pemecahannya. (Jakarta: Kencana, 2011). h.47.

Sumanto. 2014. Psikologi umum. Yogyakarta: PT. Buku seru

Sugihartono, dkk, 2007. Psikologi Pendidikan. Yogyakarta: UNY Pers.

Mulyana, Deddy. (2005) . Ilmu Komunikasi Suatu Pengantar. Bandung: PT. Remaja Rosdakarya

Widya, G. 2010. Punk Ideologi Yang Disalah Pahami. Jogjakarta: Garasi House Of Book 